International Journal of Heritage, Tourism and Hospitality Vol. (12), No. (2/2), September, 2018 By: Faculty of Tourism and Hotels, Fayoum University, Egypt

\title{
Evaluation of Housekeeping Quality Service in Egyptian Hospitals: Public vs
}

\section{Private}

Ayda Fayz Saber ${ }^{1} \quad$ Sanaa Saad Eldin Hamed ${ }^{2}$

${ }^{1}$ Faculty of Tourism and Hotel Management, Helwan University

${ }^{2}$ Institute for Tourism and Hotels- College of Technology

\begin{abstract}
Housekeeping services in a hospital is entrusted with maintaining a hygienic and clean hospital environment conducive to patient care. Housekeeping services have a direct effect on the health, comfort and morale of the patient, staff and visitors, hence is also an important public relations variable. The study was conducted on a sample of sixteen hospitals in Egypt. The chosen of hospitals was due to Public Vs private hospitals accordance to variety of the locations in Cairo, Luxor and Aswan, 500 questionnaires collected from the patients and their families through the period of May to August 2018. 421 of them were valid with rate $84.2 \%$ in the investigated hospitals. The aim of the questionnaire is to assess the level of housekeeping services and personal hygiene habits as well as their effects on patients' satisfaction. Most of the governmental hospitals being surveyed highlighted that room cleaning producers employees do and room cleaning bathroom producers employees do are still below the desired standard. Besides, housekeeping managerial skills in governmental hospitals are poor. On the other side, results obtained from the private hospitals highlighted that the applicable housekeeping procedures are more positive than proactive. Specific recommendations were suggested concerning the issue being researched.
\end{abstract}

Keywords: Good housekeeping, Environmental cleaning, patient and hospital.

\section{Introduction}

One of the most important in the hospital environment and considered as basic measures for the maintenance of hygiene, is particularly is cleaning (Russell, 1992). Environmental cleaning is a very important part of infection prevention and control in a health facility. If housekeeping is not done systematically and regularly the health care setting can become a reservoir for infectious agents (Gauthier, 2004). Patients may spread microorganisms into the health care environment, particularly if they are coughing, sneezing or having vomiting or diarrhea. Bacteria and viruses may survive for weeks or months on surfaces in the environment of the patient. The purpose of environmental cleaning is to reduce the number and amount of microorganisms and therefore reduce the risk of infection to patients and staff. Emphasizing the role of housekeeping (Johnson, 2004) pointed that "employees working in housekeeping undertake an important task in building up hospital's image and reputation. Therefore, of the problem study is to evaluate and compare between the housekeeping quality services in Egyptian hospitals: Public Vs private in order to improve the skills and minimize the gap of quality between the public and private hospitals.

\section{Research objectives}

The objectives of the current research are to: Evaluate the housekeeping quality system implemented in investigated hospitals. Assess the procedures of housekeeping's process in the selected sample. Evaluate housekeeping cleanliness, safety, and general atmosphere of rooms in the investigated hospitals 


\section{Research Problem}

The research problem is the low quality of housekeeping services in the hospitals sector. The role of housekeeping practices in the success of hospitals businesses cannot be denied. It is vital for the hospital managers to have a good understanding on what exactly need to improve the level of the service and assuring their satisfaction.

\section{Research Hypotheses}

H1: There is a correlation between all the proposed relations (the basic procedures; personal hygiene habits; room cleaning producers; isolation room cleaning producers).

$\mathrm{H} 2$ : There is a significant difference between the housekeeping quality level in the governmental and private hospitals.

\section{Research importance}

Firstly: Evaluate housekeeping quality service in Egyptian hospitals: Public Vs private in order to find out the week points and try to find reconditions to improve housekeeping programs in the sector of hospital industry could result in.

Secondly: Housekeeping effective helps in prevention and control of hospital infection, reduces cost of medical care and reduce suffering of patients.

\section{Review of literature}

An overview of hospital acquired infections

According to the World Health Organization a Hospital Acquired Infection is, "an infection acquired in hospital by a patient who was admitted for a reason other than that infection. This includes infections acquired in the hospital but appearing after discharge and also occupational infections among staff of the facility" (Prevention of hospital, 2002). In other words nosocomial infections are those infections acquired in hospital or healthcare service unit that first appear 48 hours or more after hospital admission or within 30 days after discharge following in-patient care (Nosocomial infection, 2009).

\section{The hospital hygiene and cleaning service}

Cleaning is a common activity performed to maintain a healthy, safe, and aesthetically pleasing environment. Various cleaning products have become ubiquitous parts of our everyday lives. There is increasing evidence that cleaning is related to asthma and other respiratory illnesses among those who perform cleaning tasks or spend time in recently cleaned indoor environments. While cleaning is common in nearly all industry sectors and in homes, it is particularly important in healthcare which requires intensive and frequent cleaning and uses a wide range of cleaning and disinfecting products (Branson, 2016). Cleaning in healthcare serves the dual functions of providing surface cleanliness and infection prevention and control. Both the importance and complexity of infection prevention and control are increasing due to rapidly developing strains of multidrug-resistant organisms that can result in serious worker and patient illness and even death. The recent decision of the Center for Medicare and Medicaid Services (CMS) that it will no longer provide additional reimbursement to hospitals for specific hospital-acquired infections may add a strong economic incentive for infection prevention and control measures, including the use of more cleaners and disinfectants. More importantly the media attention to certain antibioticresistant organisms such as Methicillin-resistant Staphylococcus aureus (MRSA) or infectious agents that form spores has intensified interest in cleaning and disinfection in healthcare facilities (Pia, 2009) 


\section{Quality and hospital housekeeping}

Housekeeping services in a hospital is entrusted with maintaining a hygienic and clean hospital environment conductive activity which is performed in every department of the hospital. Housekeeping services has a direct effect on the health, comfort and morale of the patient, staff and visitors, hence is also an important public relations variable (Madhav, 2016).

\section{Biomedical waste management}

From point of (Navreet. 2016) handling and Segregation of bio-medical waste is done at the point of generation/source and is put into a different color bags in same color bins. The "Bio Medical Waste Management and Handling Rules, 1998" are followed for the proper handling and final disposal of Bio Medical Waste. Biomedical waste is the leading cause for spreading of nosocomial infections in the hospital. Improper maintenance of Biomedical Waste may lead to increased risk of blood born; air born and needle prick injuries in the staff as well as the patients and their attendants. For Proper treatment and Disposal of Biomedical Waste in the facility following steps should be:

1. Segregate waste as soon as it is generated into different categories of waste.

2. Collect the waste in properly labeled specific color coded covered bins.

3. Keep same color bags in the bins.

4. Clean regularly with soap and water and disinfect the bins.

5. Collect the domestic waste (eatables, wrappers, fruit peels, papers etc., in green bin).

6. Use dedicated waste collection bins/trolleys/ wheel barrows for transporting waste.

7. Transport waste through a pre- defined route and time within the hospital.

8. Mutilate and disinfect the needle soon after administration of injection.

9. Mutilate and disinfect solid waste (plastic waste) as soon as it is generated.

10. Always disinfect the sharps and the solid waste with either hypochlorite solution or Bleaching powder before disposing.

11. Disinfect needle and solid waste (plastic) after mutilation.

12. Dispose body parts in yellow bin.

13. Dispose waste within 48 hours.

14. Always use protective gears while handling the waste. (Satter \& Hall, 2007).

15. Never mix infectious and non- infectious waste

16. Never mix plastic wastes with the waste which goes for incineration.

17. Never overfill the bins.

18. Never store waste beyond 48 hours.

19. There should not be any spillage of waste on the way of transport.

20. Avoid transport of waste through crowded areas.

21. Do not put infectious waste into general waste.

22. Don't dispose waste sharps with other wastes.

23. Don't dispose the solid waste and sharp waste without mutilation and disinfection.

24. Overloading of the Bags and the bins should be avoided. Color coded bags to be replaced when half full.

25. Never drag filled waste liners (Satter \& Hall, 2007).

Personnel Safety and Universal Precautions in hospital

In a hospital setting personnel protection should be considered as the utmost priority (Paraschivescu, 2011). The principle of universal precautions is to provide a barrier between the HCW and the patient's body substance when they have to come in close 
proximity. Blood, cerebrospinal fluid, synovial fluid, pleural fluid, pericardial fluid, peritoneal fluid, amniotic fluid, salival in dental procedures, semen, vaginal secretions, any body fluid that is visibly contaminated with blood; any unfixed tissue or organ from a human ; HIV containing culture medium or other solutions; blood or other tissues infected with HIV or hepatitis B, C or non A non B are considered as the source of potential infection, for which following Precautions and instructions should be followed:

Table 1: Precautions and instructions of potential infection

\begin{tabular}{|c|c|}
\hline Barrier & User of Barrier \\
\hline Hand washing & $\begin{array}{l}\text { Before and after patient contact after using gloves, } \\
\text { immediately after contact with blood and care workers } \\
\text { who have exudative lesions or weeping dermatitis should } \\
\text { refrain from all patient care activities that involve direct } \\
\text { contact and from handling patient care equipment } \\
\text { (Kayakalp, 2015). }\end{array}$ \\
\hline $\begin{array}{l}\text { Masks and other } \\
\text { protective equipment } \\
\text { such as face shields and } \\
\text { goggles }\end{array}$ & $\begin{array}{l}\text { When one is likely to be splashed in the face with } \\
\text { infective material, which may lead to contamination of } \\
\text { the eyes, nose or mouth (Carling, 2013). }\end{array}$ \\
\hline Gloves & $\begin{array}{l}\text { When direct contact with blood and body fluids, mucous } \\
\text { membranes non-intact skin surfaces or infectious } \\
\text { material is anticipated when performing vascular access } \\
\text { or other invasive procedures and when handling } \\
\text { specimens, cultures, or tissues that are visibly } \\
\text { contaminated with blood or other infectious material } \\
\text { (Hoes, 2013). Hands must be washed each time gloves } \\
\text { are removed. Those with non-intact skin must wear } \\
\text { gloves when indirect handling of infectious material is a } \\
\text { possibility. }\end{array}$ \\
\hline $\begin{array}{l}\text { Protective clothing } \\
\text { Gowns, lab coats, caps, } \\
\text { hoods, shoe covers, } \\
\text { boots, or other such } \\
\text { paraphernalia }\end{array}$ & $\begin{array}{l}\text { When the HCW is likely to be soiled by the splattering } \\
\text { of infectious material. These must be removed and } \\
\text { discarded properly immediately after use. }\end{array}$ \\
\hline $\begin{array}{l}\text { Handling Needles and } \\
\text { small sharps }\end{array}$ & $\begin{array}{l}\text { Never recap or bend the needles unless by using an } \\
\text { instrument or by no touch technique. } \\
\text { Dispose of used needles and disposable small sharps in } \\
\text { puncture proof containers that are located as close to the } \\
\text { area of use as possible (Moore, 2013). }\end{array}$ \\
\hline
\end{tabular}

Source: WHO Guidelines on Hand Hygiene in Health Care (Advanced draft), at:

http://www.who.int/patientsafety/information_centre/ghhad_download/en/index.html. (Accessed 25/7/2018).

\section{Protocols for Gloves}

1. Use of disposable gloves to be ensured

2. In high risk cases; double gloving should be done; routine cases single

3. Gloves should be changed if duration of procedure/operation is $>3$ hours

4. Any pair of gloves can be used for total time of 3 hours

5. Between patients; gloved hands should be disinfected for at least 30 seconds

6. Surgical hygienic hand (w) should be done before and after use of gloves 
7. Check gloves for gross defects before putting on cover cuts with waterproof dressing before gloving

8. Discard gloves immediately on suspicion of puncture (Rutala, 2013).

Protocols for Masks

1. Masks are mandatory for infections patients' esp. airborne infection

2. Ideally masks should be disposable; if not cotton masks can be used

3. Masks should fit properly and cover both mouth and nose.

4. Masks should be changed after every proc/surgery lasting $>20$ minutes.

5. Cotton masks should be disinfected with liquid bleach before washing and reuse (Elizabeth, 2014).

Safe handling of sharps

1. Pass syringes and needles in a tray cut it with electric /manual needle cutlers after use

2. Put needle and syringes in a puncture proof white container, containing $2 \%$ hypochlorite solution

3. Remove cap of needle near the site of use

4. Pick up open needle from tray/drum with forceps

5. Destroy syringes by burning their tips/cutters not available

6. Never pass syringe and needle on directly to next person

7. Do not bent/or break used needle with hands

8. Never test the fineness of the needle's tip before use with bare or gloved hand

9. Never pick up open needle by hand

10. Never dispose it off by breaking it with hammer/stone

11. Always dispose of your own sharps, into a sharp pit

12. During exposure-prone procedure, the risk of injury should be minimized by ensuring that the operator has the best possible visibility for example by positioning the patient, adjusting good light source and controlling bleeding (Vintila,2009).

Protocols for Mercury Spillage

1. Remove everyone from the area that has been contaminated with mercury.

2. Keep the heat below $200 \mathrm{C}$ and ventilate the area.

3. Put on face mask in order to prevent breathing of mercury vapor.

4. Remove all jewelry from hands and wrists.

5. Use Personal Protective Equipment while handling mercury.

6. Cardboard sheets should be used to locate and push the spilled beads of mercury together.

7. Mercury should be placed carefully in a container with some water.

8. . Never us a broom or vacuum cleaner.

9. It should be disposed of at hazardous waste facility or given to a mercury-based equipment manufacturer (Rennie, 2016)

Protocols for cleaning Spillage of Blood

1. Wear gloves

2. Pour, without splashing, a disinfectant appropriate for the size and surface contaminated, e.g. Isopropyl alcohol, Dakin's or house hold bleach 1: 100 dil or 1: 10 dilution.

3. Place absorbent paper (e.g. news / tissue paper over the spill. Allow a contact time of 20 minutes.

4. Wipe up the spill. Put absorbent paper in the yellow bag. Wash hands (with gloves on).

5. Remove gloves. 
6. Wash hands. (Anderson, 2013).

\section{Cleaning Practices for all health care setting}

\begin{tabular}{|c|c|}
\hline $\begin{array}{l}\text { Before } \\
\text { Cleaning }\end{array}$ & $\begin{array}{l}\text { - Check for Additional Precautions signs. } \\
\text { - Follow precautions as indicated. } \\
\text { - Remove clutter before cleaning. } \\
\text { - Follow the manufacturer's instructions for proper mixing and required } \\
\text { contact time for disinfectant solutions. } \\
\text { - Gather materials required for cleaning before entering the room. } \\
\text { - Clean hands on entering the room. }\end{array}$ \\
\hline $\begin{array}{l}\text { During } \\
\text { Cleaning }\end{array}$ & $\begin{array}{l}\text { - Progress from the least soiled areas (low-touch) to the most soiled areas } \\
\text { (high-touch) and from high surfaces to low surfaces. } \\
\text { - Remove gross soil prior to cleaning and disinfection. } \\
\text { - Dry mopping is done before damp mopping. } \\
\text { - Minimize turbulence to prevent the mobilization of dust that may contain } \\
\text { microorganisms } \\
\text { - Never shake mops inside to minimize dust/dirt in air. Ideally remove } \\
\text { large pieces of dust and dirt with gloved hands then remove mop head to } \\
\text { be laundered (Munoz-Price, 2013). } \\
\text { - . Do not "double-dip" cloths. } \\
\text { - Change cloths/mop heads frequently. } \\
\text { - Change cleaning solutions as per manufacturer's instructions. Change } \\
\text { more frequently in heavily contaminated areas, when visibly soiled and } \\
\text { immediately after cleaning a blood and body fluid spill. (Otter, Yezli \& } \\
\text { French, 2015). } \\
\text { - Containers for liquid soap and cleaners/disinfectants are disposable. The } \\
\text { practice of 'topping up' is not acceptable as it can result in contamination } \\
\text { of the container and solution. } \\
\text { - Vacuum carpets using vacuums fitted with a HEPA filter. } \\
\text { - Maintain the filter according to the manufacturer's instructions. } \\
\text { - Be alert for needles and other sharp items. Pick up sharps using a } \\
\text { mechanical device (if possible) such as tongs and place into sharps } \\
\text { container. } \\
\text { - Report such incidents to the supervisor } \\
\text { - Collect plastic waste bags handling them from the top and do not } \\
\text { compress. } \\
\text { - Perform hand hygiene before putting on a clean pair of disposable gloves } \\
\text { - Change gloves frequently including when leaving a room or area. } \\
\text { - Avoid spraying cleaning solutions onto a surface to reduce exposure to } \\
\text { aerosolized cleaning chemical. Spray directly onto cleaning cloth instead. }\end{array}$ \\
\hline $\begin{array}{l}\text { After } \\
\text { Cleaning }\end{array}$ & $\begin{array}{l}\text { - Do not overstock rooms with supplies such as toilet paper and paper } \\
\text { towels. } \\
\text { - Equipment used for cleaning/disinfecting must be cleaned and dried } \\
\text { between uses. } \\
\text { - Launder mop heads daily with all washed mops heads being dried } \\
\text { thoroughly in dryer before re-using. } \\
\text { - Clean the housekeeping cart as well as the carts used to transport waste } \\
\text { daily. (Centers for Disease Control and Prevention., 2014) }\end{array}$ \\
\hline
\end{tabular}




\section{Materials and methodology}

Regarding the research methods this research uses the descriptive approach. Research design was quantitative study in order to evaluate housekeeping quality in Egyptian hospitals. Moreover, About Population of the study this study geographical limit was the Egyptian hospitals in Cairo and Luxor and Aswan, through the period of May to August 2018. The field of study was accomplished through self-administered questionnaires, which includes some attributes that may influence Patient' choice as well as their evaluation for housekeeping quality in Egyptian hospitals.

The questionnaire design was prepared for this study is based on a comprehensive literature review. It is translated from English into Arabic. The Five-level Likert scale ranging from 1 " was compliant "to 5 " was excellent" was used to design the questionnaire form. The questionnaire was divided into seven main sections: the first section: includes some of basic procedures. The second section: personal hygiene habits. The third section: focus on the patient room cleaning producers. The fourth section: patient room cleaning bathroom producers. The fifth section: isolation room cleaning producers. The sixth section: use only one-time cleaning pieces. The seventh section: wear single-use protective clothing (PPE) such as gloves, headgear, shoes, etc. contaminated with medicine.

The self-administrated questionnaire adopted based on (Satter and Hall, 2007; Vintila, 2009; Kayakalp, 2015) was established in order to investigate the Patients and their families in the investigated hospitals in regard to evaluate of housekeeping quality in Egyptian hospitals. Pilot study was conducted in this study during May to June 2018. The aim of the pilot study was to ensure that the survey was well designed and easily understood by potential respondents, to examine the reliability and validity of the research tools as well as to develop and refine measure of the questions. Questionnaire was reviewed by some academic scholars to establish their appropriateness, clarity and to ease the understanding. Some amendments were suggested and then were implemented. Questionnaire was then pre-tested in order to investigate the respondent's understanding of scale items and to identify also any issues that was complex or confusing in order to develop appropriate scale items to ensure the validity and reliability of the research. For this purpose, a self-administered questionnaire was distributed to a sample of supervisors and managers. A number of 30 forms were distributed to respondents who were asked to complete them. Only, 21 completed forms were valid which represents $70 \%$ rate of response.

500 questionnaires collected through the period of June to August 2018 from the Patients and their families in the investigated hospitals; only 421 of them were valid by average $84.2 \%$ in the investigated hospitals. The aim of the questionnaire is to examine the level of housekeeping services and personal hygiene habits as well as their effects on satisfaction. The main purpose of this questionnaire was to evaluate housekeeping quality in Egyptian hospitals to meet the international standard level. The results obtained from the valid forms which statistically analyzed by using SPSS version 20 .

\section{The Sample Population}

The study was conducted on a sample of sixteen hospitals in Egypt. The chosen of hospitals was due to variety of the locations in Luxor and Aswan. The hospitals samples are as follows in table (2). 
International Journal of Heritage, Tourism and Hospitality Vol. (12), No. (2/2), September, 2018 By: Faculty of Tourism and Hotels, Fayoum University, Egypt

Table 2: The Sample Population

\begin{tabular}{|l|l|l|l|}
\hline No. & name of the hospital & $\begin{array}{l}\text { Type of } \\
\text { hospital }\end{array}$ & Location \\
\hline 1. & Nagaa Hammadi General Hospital & Governmental & Luxor \\
\hline 2. & Naqada Fever Hospital & Governmental & Luxor \\
\hline 3. & Luxor General Hospital & Governmental & Luxor \\
\hline 4. & Aswan Health Insurance Hospital & Governmental & Aswan \\
\hline 5. & Al Qurna Central Hospital & Governmental & Luxor \\
\hline 6. & Aswan Teaching Hospital & Governmental & Aswan \\
\hline 7. & El Matareya Teaching Hospital & Governmental & Cairo \\
\hline 8. & Nile Hospital & Private & Luxor \\
\hline 9. & Esna Central Hospital & Governmental & Luxor \\
\hline 10. & Luxor International Hospital & Private & Luxor \\
\hline 11. & Nile Badrawi & Private & Cairo \\
\hline 12. & Cairo University Hospitals & Governmental & Cairo \\
\hline 13. & Ain Shams University Private Hospitals & Private & Cairo \\
\hline 14. & Nasr City General Hospital for Health Insurance & Governmental & Cairo \\
\hline 15. & Manial National Hospital & Governmental & Cairo \\
\hline 16. & Al Qasr Al Aini Hospitals & Governmental & Cairo \\
\hline
\end{tabular}

\section{1- Instrument Reliability}

For all scales, Cranach alpha correlation coefficient was calculated to determine the internal consistency of the scale. The Cranach Alpha reliability was computed and the tests showed that the reliability coefficients for all the instruments were 0.997 , which indicates that the instrument is reliable as shown in table 3:

Table3: Reliability Statistics

\begin{tabular}{|c|c|c|}
\hline Cranach's Alpha & No. of Items & No. of respondents \\
\hline .997 & 106 & 421 \\
\hline
\end{tabular}

\section{2- Data analysis}

The Statistic Package of the Social Sciences (SPSS v 20.0) was applied in order to analyze the data obtained in this study. Simple frequencies, mean ratings, standard deviation, standard deviation error, and ranking have been computed to classify the sets and find out whether the sample is homogenous or inconsistent, with regard to all research variables.

\section{3- Results and discussion}

Table (3) showed the respondents' opinions toward housekeeping in the governmental and private hospitals. For the following items with from 1 to 5 Likert scale. Where (1) means Compliant "; (5) is Excellent. Concerning respondents' opinion regarding the basic procedures, the respondents' perceptions can be ranked as follows; the private hospitals collect the garbage in the bag (without compression and compression in the bag) and carry the bag from the top were considered the highest level factor with weighted average (94.30), followed by employees wears slip-resistant soles shoes to avoid injuries, slips and falls in the second position by weighted average (92.40). Moreover, Employees always knock and enter slowly, while cleaning the room realized the third position by weighted average (82.52). Employees always knock and enter slowly, while cleaning the move furniture in order to clean the space in the fourth position by weighted average (80.19). While, Employees performs hand 
hygiene and done gloves before entering the room achieved the fifth position by weighted average (76.39). These results agree with opining of (Paraschivescu, 2011).

On the other hand for the governmental hospitals results showed that cleaners are familiar with the safety evidence on the packaging of chemicals used for cleaning were considered the highest level factor with weighted average (51.45), followed by both cleaners are familiar with the treatment of medical waste and its seriousness in hospitals, and employees wears slip-resistant soles shoes to avoid injuries, slips and falls by weighted average (46.70) This result disagree with opining of(Paraschivescu, 2011). Moreover, Collect the garbage in the bag (without compression and compression in the bag) and carry the bag from the top realized the third position by weighted average (44.89) This result confuse with opining of(Satter and Hall, 2007).

Employees have to move furniture in order to clean the space in the fourth position by weighted average (44.80). While, general cleaning shall be carried out at least twice, in the morning before work begins and the evening after the completion of the work were achieved the fifth position by weighted average (40.52). These results disagree with opining of (Centers for Disease Control and Prevention, 2014).

Concerning respondents' opinion regarding personal hygiene habits, the respondents' perceptions can be displayed as follows: Regarding the private hospitals employees wear a special clean uniform, comes in the first rank with a percentage estimated at (97.15) of answers; followed by employees avoid smoking in work areas recorded the second rank with percentage of (92.40) of responses; While, Both Employees avoid: Eating and drinking in work areas; and using pillowcase, sheets or towels for cleaning comes on the third rank by average (84.80) of answers; Moreover, employees avoid chewing gum at work reaches the fourth rank with the ratio of (72.40) of responses; Furthermore, Employees know sanitation and hygiene rules come as the fifth rank by average (66.70) of answers. 
International Journal of Heritage, Tourism and Hospitality Vol. (12), No. (2/2), September, 2018

By: Faculty of Tourism and Hotels, Fayoum University, Egypt

Table 4: The respondents' opinions toward housekeeping in the governmental and private hospitals.

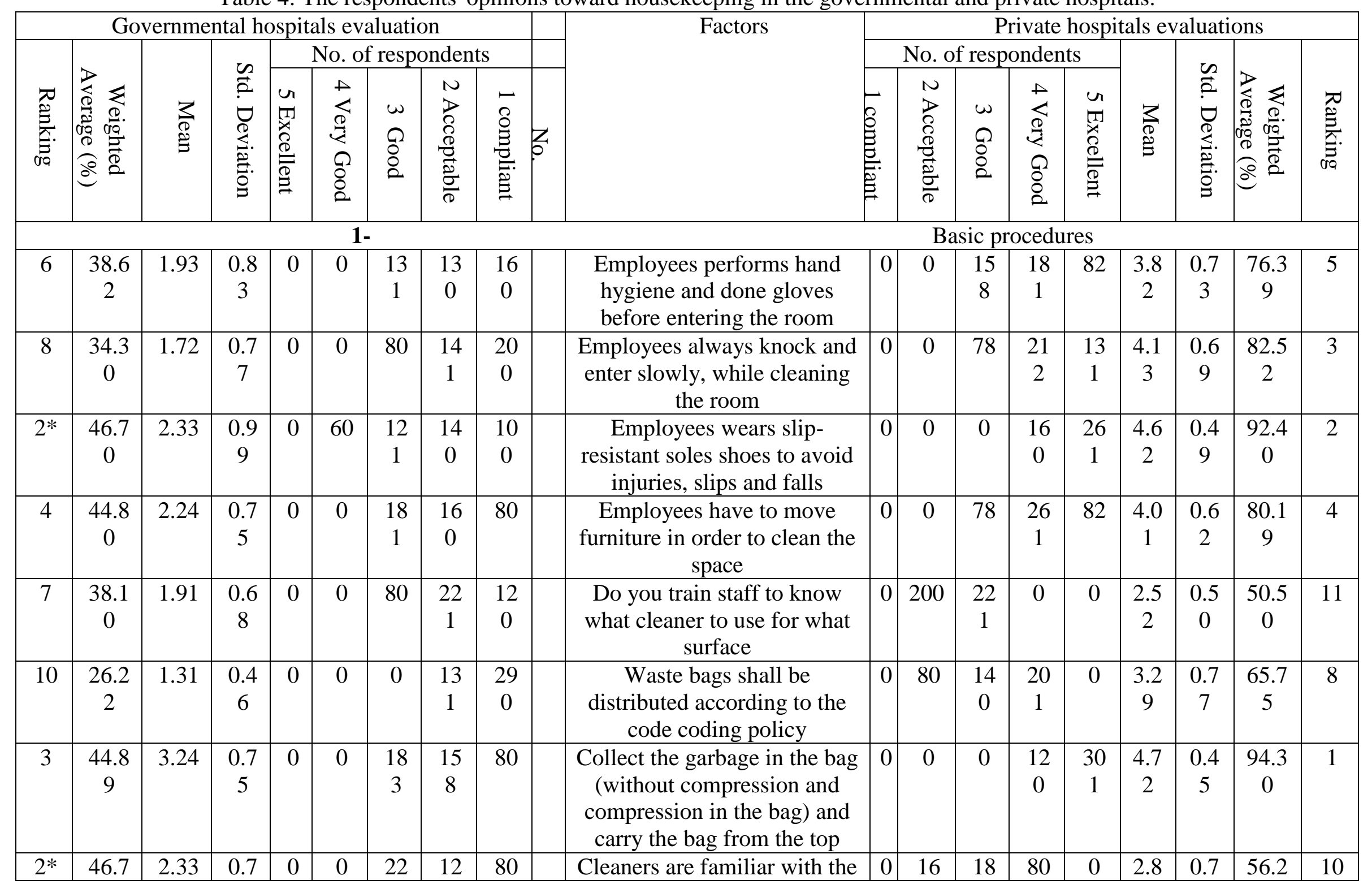


International Journal of Heritage, Tourism and Hospitality Vol. (12), No. (2/2), September, 2018

By: Faculty of Tourism and Hotels, Fayoum University, Egypt

\begin{tabular}{|c|c|c|c|c|c|c|c|c|c|c|c|c|c|c|c|c|c|c|}
\hline & 0 & & 8 & & & 1 & 0 & & $\begin{array}{l}\text { treatment of medical waste } \\
\text { and its seriousness in } \\
\text { hospitals. }\end{array}$ & & 0 & 1 & & & 1 & 3 & 0 & \\
\hline 1 & $\begin{array}{c}51.4 \\
5\end{array}$ & 2.57 & $\begin{array}{c}0.6 \\
6\end{array}$ & 0 & 0 & $\begin{array}{c}28 \\
1\end{array}$ & $\begin{array}{c}10 \\
0\end{array}$ & 40 & $\begin{array}{l}\text { Cleaners are familiar with the } \\
\text { safety evidence on the } \\
\text { packaging of chemicals used } \\
\text { for cleaning }\end{array}$ & 0 & $\begin{array}{c}12 \\
0\end{array}$ & $\begin{array}{c}20 \\
0\end{array}$ & $\begin{array}{c}10 \\
1\end{array}$ & 0 & $\begin{array}{c}2.9 \\
5\end{array}$ & $\begin{array}{c}0.7 \\
2\end{array}$ & $\begin{array}{c}59.1 \\
0\end{array}$ & 9 \\
\hline 5 & $\begin{array}{c}40.5 \\
2\end{array}$ & 2.03 & $\begin{array}{c}0.7 \\
7\end{array}$ & 0 & 0 & $\begin{array}{c}13 \\
1\end{array}$ & $\begin{array}{c}17 \\
0\end{array}$ & $\begin{array}{c}12 \\
0\end{array}$ & $\begin{array}{l}\text { General cleaning shall be } \\
\text { carried out at least twice, in } \\
\text { the morning before work } \\
\text { begins and the evening after } \\
\text { the completion of the work }\end{array}$ & 0 & 0 & $\begin{array}{c}19 \\
8\end{array}$ & $\begin{array}{c}14 \\
1\end{array}$ & 82 & $\begin{array}{c}3.7 \\
2\end{array}$ & $\begin{array}{c}0.7 \\
7\end{array}$ & $\begin{array}{c}74.4 \\
9\end{array}$ & 6 \\
\hline 9 & $\begin{array}{c}32.4 \\
0\end{array}$ & 1.62 & $\begin{array}{c}0.6 \\
5\end{array}$ & 0 & 0 & 40 & $\begin{array}{c}18 \\
1\end{array}$ & $\begin{array}{c}20 \\
0\end{array}$ & $\begin{array}{c}\text { Provide separate buckets to } \\
\text { clean the bathrooms and all } \\
\text { the isolation rooms }\end{array}$ & 0 & 40 & $\begin{array}{c}18 \\
0\end{array}$ & $\begin{array}{c}20 \\
1\end{array}$ & 0 & $\begin{array}{c}3.3 \\
8\end{array}$ & $\begin{array}{c}0.6 \\
5\end{array}$ & $\begin{array}{c}67.6 \\
5\end{array}$ & 7 \\
\hline \multicolumn{19}{|c|}{ 2- Personal hygiene habits } \\
\hline 4 & $\begin{array}{c}44.7 \\
0\end{array}$ & 2.24 & $\begin{array}{c}0.7 \\
5\end{array}$ & 0 & 0 & $\begin{array}{c}17 \\
9\end{array}$ & $\begin{array}{l}16 \\
2\end{array}$ & 80 & $\begin{array}{c}\text { 1. Employees knows } \\
\text { sanitation and hygiene rules }\end{array}$ & 0 & 80 & $\begin{array}{c}12 \\
0\end{array}$ & $\begin{array}{c}22 \\
1\end{array}$ & 0 & $\begin{array}{c}3.3 \\
3\end{array}$ & $\begin{array}{c}0.7 \\
8\end{array}$ & $\begin{array}{c}66.7 \\
0\end{array}$ & 5 \\
\hline $1 *$ & $\begin{array}{c}72.4 \\
0\end{array}$ & 3.62 & $\begin{array}{c}0.4 \\
9\end{array}$ & 0 & $\begin{array}{c}26 \\
1\end{array}$ & $\begin{array}{c}16 \\
0\end{array}$ & 0 & 0 & $\begin{array}{l}\text { 2. Employees wear a special } \\
\text { clean uniform }\end{array}$ & 0 & 0 & 0 & 60 & $\begin{array}{c}36 \\
1 \\
\end{array}$ & $\begin{array}{c}4.8 \\
6\end{array}$ & $\begin{array}{c}0.3 \\
5\end{array}$ & $\begin{array}{c}97.1 \\
5\end{array}$ & 1 \\
\hline 5 & $\begin{array}{c}34.3 \\
0\end{array}$ & 1.72 & $\begin{array}{c}0.7 \\
7\end{array}$ & 0 & 0 & 80 & $\begin{array}{c}14 \\
1\end{array}$ & $\begin{array}{c}20 \\
0\end{array}$ & $\begin{array}{l}\text { 3. Employees changes } \\
\text { uniform daily }\end{array}$ & 0 & 80 & $\begin{array}{c}26 \\
1\end{array}$ & 80 & 0 & $\begin{array}{c}3.0 \\
0\end{array}$ & $\begin{array}{c}0.6 \\
2\end{array}$ & $\begin{array}{c}60.0 \\
0 \\
\end{array}$ & 6 \\
\hline & & \multicolumn{15}{|c|}{ Employees avoid: } & & \\
\hline 7 & $\begin{array}{c}28.6 \\
0\end{array}$ & 1.72 & $\begin{array}{c}0.6 \\
3\end{array}$ & 0 & 0 & 40 & $\begin{array}{c}22 \\
1\end{array}$ & 40 & a. Smoking in work areas & 0 & 0 & 40 & 80 & $\begin{array}{c}30 \\
1 \\
\end{array}$ & $\begin{array}{c}4.6 \\
2 \\
\end{array}$ & $\begin{array}{c}0.6 \\
5\end{array}$ & $\begin{array}{c}92.4 \\
0 \\
\end{array}$ & 2 \\
\hline 6 & $\begin{array}{c}31.3 \\
5\end{array}$ & 1.57 & $\begin{array}{c}0.5 \\
0\end{array}$ & 0 & 0 & 0 & $\begin{array}{c}23 \\
9\end{array}$ & $\begin{array}{c}18 \\
2\end{array}$ & $\begin{array}{l}\text { b. Eating and drinking in } \\
\text { work areas }\end{array}$ & 0 & 0 & 80 & $\begin{array}{c}16 \\
0\end{array}$ & $\begin{array}{c}18 \\
1\end{array}$ & $\begin{array}{c}4.2 \\
4\end{array}$ & $\begin{array}{c}0.7 \\
5\end{array}$ & $\begin{array}{c}84.8 \\
0\end{array}$ & $3 *$ \\
\hline 3 & $\begin{array}{c}46.7 \\
0\end{array}$ & 2.33 & $\begin{array}{c}0.7 \\
8\end{array}$ & 0 & 0 & $\begin{array}{c}22 \\
1\end{array}$ & $\begin{array}{c}12 \\
0\end{array}$ & 80 & c. Chewing gum at work & 0 & 0 & $\begin{array}{c}16 \\
0\end{array}$ & $\begin{array}{c}26 \\
1\end{array}$ & 0 & $\begin{array}{c}3.6 \\
2\end{array}$ & $\begin{array}{c}0.4 \\
9\end{array}$ & $\begin{array}{c}72.4 \\
0\end{array}$ & 4 \\
\hline 2 & $\begin{array}{c}60.5 \\
2\end{array}$ & 3.03 & $\begin{array}{c}0.7 \\
7\end{array}$ & 0 & $\begin{array}{c}13 \\
1\end{array}$ & $\begin{array}{c}17 \\
0\end{array}$ & $\begin{array}{c}12 \\
0\end{array}$ & 0 & $\begin{array}{l}\text { d. Spitting on the floor in } \\
\text { work and back areas }\end{array}$ & 0 & 0 & 80 & $\begin{array}{c}16 \\
0\end{array}$ & $\begin{array}{c}18 \\
1 \\
\end{array}$ & $\begin{array}{c}4.2 \\
4\end{array}$ & $\begin{array}{c}0.7 \\
5\end{array}$ & $\begin{array}{c}84.8 \\
0\end{array}$ & $3 *$ \\
\hline 8 & $\begin{array}{c}23.8 \\
0\end{array}$ & 1.19 & $\begin{array}{c}0.3 \\
9\end{array}$ & 0 & & 0 & 80 & $\begin{array}{c}34 \\
1\end{array}$ & e. Touching their body parts & 0 & $\begin{array}{c}20 \\
2\end{array}$ & $\begin{array}{c}14 \\
1\end{array}$ & 78 & & $\begin{array}{c}2.7 \\
1\end{array}$ & $\begin{array}{c}0.7 \\
6\end{array}$ & $\begin{array}{c}54.1 \\
1\end{array}$ & 7 \\
\hline
\end{tabular}


International Journal of Heritage, Tourism and Hospitality Vol. (12), No. (2/2), September, 2018

By: Faculty of Tourism and Hotels, Fayoum University, Egypt

\begin{tabular}{|c|c|c|c|c|c|c|c|c|c|c|c|c|c|c|c|c|c|c|}
\hline $1 *$ & $\begin{array}{c}72.4 \\
0\end{array}$ & 3.62 & $\begin{array}{c}0.4 \\
9\end{array}$ & 0 & $\begin{array}{c}26 \\
1\end{array}$ & $\begin{array}{c}16 \\
0\end{array}$ & 0 & 0 & $\begin{array}{l}\text { f. Using pillowcase, sheets or } \\
\text { towels for cleaning }\end{array}$ & 0 & 0 & $\begin{array}{c}12 \\
0\end{array}$ & 80 & $\begin{array}{c}22 \\
1\end{array}$ & $\begin{array}{c}4.2 \\
4\end{array}$ & $\begin{array}{c}0.8 \\
7\end{array}$ & $\begin{array}{c}84.8 \\
0\end{array}$ & $3 *$ \\
\hline \multicolumn{19}{|c|}{ 3. Patient room cleaning producers Employees Do: } \\
\hline 1 & $\begin{array}{c}66.7 \\
0\end{array}$ & 3.33 & $\begin{array}{c}0.6 \\
4\end{array}$ & 0 & $\begin{array}{c}18 \\
1\end{array}$ & $\begin{array}{c}20 \\
0\end{array}$ & 40 & 0 & $\begin{array}{l}\text { 1. Review the room, change } \\
\text { the furnishings and collect } \\
\text { the remains of the medicine } \\
\text { preparation boxes and the } \\
\text { tools used to give the patient } \\
\text { such as injections, needles } \\
\text { and preparation utensils }\end{array}$ & 0 & 0 & 0 & $\begin{array}{c}12 \\
0\end{array}$ & $\begin{array}{c}30 \\
1\end{array}$ & $\begin{array}{c}4.7 \\
2\end{array}$ & $\begin{array}{c}0.4 \\
5\end{array}$ & $\begin{array}{c}94.3 \\
0\end{array}$ & 2 \\
\hline $5 *$ & $\begin{array}{c}38.6 \\
2\end{array}$ & 1.93 & $\begin{array}{c}0.8 \\
3\end{array}$ & 0 & 0 & $\begin{array}{c}13 \\
1\end{array}$ & $\begin{array}{c}13 \\
0\end{array}$ & $\begin{array}{c}16 \\
0\end{array}$ & $\begin{array}{l}\text { 2. Cleaning walls, windows } \\
\text { and doors: including door } \\
\text { handles }\end{array}$ & 0 & 40 & $\begin{array}{c}12 \\
0\end{array}$ & $\begin{array}{c}26 \\
1\end{array}$ & & $\begin{array}{c}3.5 \\
2\end{array}$ & $\begin{array}{c}0.6 \\
6\end{array}$ & $\begin{array}{c}70.5 \\
0\end{array}$ & 7 \\
\hline 6 & $\begin{array}{c}36.3 \\
9\end{array}$ & 1.82 & $\begin{array}{c}0.7 \\
3\end{array}$ & 0 & 0 & 82 & $\begin{array}{c}18 \\
1\end{array}$ & $\begin{array}{c}15 \\
8\end{array}$ & $\begin{array}{l}\text { 3. Cleaning and cleaning } \\
\text { horizontal surfaces: including } \\
\text { tables, beds, chairs, edges, } \\
\text { lighting and wall fixtures. }\end{array}$ & 0 & 0 & $\begin{array}{c}16 \\
0\end{array}$ & $\begin{array}{c}26 \\
1\end{array}$ & 0 & $\begin{array}{c}3.6 \\
2\end{array}$ & $\begin{array}{c}0.4 \\
9\end{array}$ & $\begin{array}{c}72.4 \\
0\end{array}$ & 6 \\
\hline 4 & $\begin{array}{c}42.9 \\
0\end{array}$ & 2.14 & $\begin{array}{c}0.8 \\
3\end{array}$ & 0 & 0 & $\begin{array}{c}18 \\
1\end{array}$ & $\begin{array}{c}12 \\
0\end{array}$ & $\begin{array}{c}12 \\
0\end{array}$ & $\begin{array}{l}\text { 4. Cleaning and disinfection } \\
\text { of the surface of the type } \\
\text { Frequent touch: such as edges } \\
\text { and bedspreads - Door } \\
\text { handles - Table adjacent to } \\
\text { the patient - Telephone - } \\
\text { Nurse call buttons - TV } \\
\text { remote - Lighting switches } \\
\text { must be cleaned and purified }\end{array}$ & 0 & 0 & 0 & $\begin{array}{c}14 \\
0\end{array}$ & $\begin{array}{c}28 \\
1\end{array}$ & $\begin{array}{c}4.6 \\
7\end{array}$ & $\begin{array}{c}0.4 \\
7\end{array}$ & $\begin{array}{c}93.3 \\
5\end{array}$ & 3 \\
\hline 3 & $\begin{array}{c}44.8 \\
0\end{array}$ & 2.24 & $\begin{array}{c}0.7 \\
5\end{array}$ & 0 & 0 & $\begin{array}{c}18 \\
1\end{array}$ & $\begin{array}{c}16 \\
0\end{array}$ & 80 & $\begin{array}{l}\text { 5. Garbage containers with } \\
\text { holes or openings that allow } \\
\text { fluid and waste to enter }\end{array}$ & 0 & 0 & 0 & $\begin{array}{c}16 \\
0\end{array}$ & $\begin{array}{c}26 \\
1\end{array}$ & $\begin{array}{c}4.6 \\
2\end{array}$ & $\begin{array}{c}0.4 \\
9\end{array}$ & $\begin{array}{c}92.4 \\
0\end{array}$ & 4 \\
\hline $5 *$ & $\begin{array}{c}38.6 \\
2 \\
\end{array}$ & 1.93 & $\begin{array}{c}0.8 \\
3 \\
\end{array}$ & 0 & 0 & $\begin{array}{c}13 \\
1 \\
\end{array}$ & $\begin{array}{c}13 \\
0 \\
\end{array}$ & $\begin{array}{c}16 \\
0 \\
\end{array}$ & $\begin{array}{l}\text { 6. Garbage containers with } \\
\text { tight cover }\end{array}$ & 0 & 0 & 0 & $\begin{array}{c}20 \\
0\end{array}$ & $\begin{array}{c}22 \\
1 \\
\end{array}$ & $\begin{array}{c}4.5 \\
2\end{array}$ & $\begin{array}{c}0.5 \\
0\end{array}$ & $\begin{array}{c}90.5 \\
0 \\
\end{array}$ & 5 \\
\hline 2 & $\begin{array}{c}50.5 \\
0 \\
\end{array}$ & 2.52 & $\begin{array}{c}0.5 \\
0 \\
\end{array}$ & 0 & 0 & $\begin{array}{c}22 \\
1 \\
\end{array}$ & $\begin{array}{c}20 \\
0 \\
\end{array}$ & 0 & $\begin{array}{l}\text { 7. Remove the gloves, and } \\
\text { make the hands clean after }\end{array}$ & 0 & 0 & 0 & 80 & $\begin{array}{c}34 \\
1 \\
\end{array}$ & $\begin{array}{c}4.8 \\
1 \\
\end{array}$ & $\begin{array}{c}0.3 \\
9 \\
\end{array}$ & $\begin{array}{c}96.2 \\
0 \\
\end{array}$ & 1 \\
\hline
\end{tabular}


International Journal of Heritage, Tourism and Hospitality Vol. (12), No. (2/2), September, 2018

By: Faculty of Tourism and Hotels, Fayoum University, Egypt

\begin{tabular}{|c|c|c|c|c|c|c|c|c|c|c|c|c|c|c|c|c|c|c|}
\hline & & & & & & & & & work & & & & & & & & & \\
\hline \multicolumn{19}{|c|}{ 4- Patient room cleaning bathroom producers Employees Do: } \\
\hline 5 & $\begin{array}{c}26.3 \\
7\end{array}$ & 1.32 & $\begin{array}{c}0.4 \\
7\end{array}$ & 0 & 0 & 0 & $\begin{array}{c}13 \\
4\end{array}$ & $\begin{array}{c}28 \\
7\end{array}$ & $\begin{array}{l}\text { Clean the mirror using a blue } \\
\text { Microfiber glass cloth }\end{array}$ & 0 & 80 & $\begin{array}{c}12 \\
0\end{array}$ & $\begin{array}{c}22 \\
1\end{array}$ & 0 & $\begin{array}{c}3.3 \\
3\end{array}$ & $\begin{array}{c}0.7 \\
8\end{array}$ & $\begin{array}{c}66.7 \\
0\end{array}$ & 4 \\
\hline 3 & $\begin{array}{c}31.5 \\
4\end{array}$ & 1.58 & $\begin{array}{c}0.4 \\
9\end{array}$ & 0 & 0 & 0 & $\begin{array}{c}24 \\
3\end{array}$ & $\begin{array}{c}17 \\
8\end{array}$ & $\begin{array}{l}\text { Clean the sink area, including } \\
\text { the counter, faucet and } \\
\text { handles, and sink basin with a } \\
\text { clean yellow Microfiber cloth }\end{array}$ & 0 & 120 & $\begin{array}{c}17 \\
0\end{array}$ & $\begin{array}{c}13 \\
1\end{array}$ & 0 & $\begin{array}{c}3.0 \\
3\end{array}$ & $\begin{array}{c}0.7 \\
7\end{array}$ & $\begin{array}{c}60.5 \\
2\end{array}$ & 5 \\
\hline 2 & $\begin{array}{c}43.8 \\
5\end{array}$ & 2.19 & $\begin{array}{c}0.8 \\
5\end{array}$ & 0 & 0 & $\begin{array}{c}20 \\
1\end{array}$ & $\begin{array}{c}10 \\
0\end{array}$ & $\begin{array}{c}12 \\
0\end{array}$ & Disinfect toilet & 0 & 0 & 0 & $\begin{array}{c}14 \\
0\end{array}$ & $\begin{array}{c}28 \\
1\end{array}$ & $\begin{array}{c}4.6 \\
7\end{array}$ & $\begin{array}{c}0.4 \\
7\end{array}$ & $\begin{array}{c}93.3 \\
5\end{array}$ & 1 \\
\hline 1 & $\begin{array}{c}46.7 \\
0\end{array}$ & 2.33 & $\begin{array}{c}0.7 \\
8\end{array}$ & 0 & 0 & $\begin{array}{c}22 \\
1\end{array}$ & $\begin{array}{c}12 \\
0\end{array}$ & 80 & Restock consumable supplies & 0 & 0 & 0 & $\begin{array}{c}16 \\
2\end{array}$ & $\begin{array}{c}25 \\
9\end{array}$ & $\begin{array}{c}4.6 \\
2\end{array}$ & $\begin{array}{c}0.4 \\
9\end{array}$ & $\begin{array}{c}92.3 \\
0\end{array}$ & 2 \\
\hline 4 & $\begin{array}{c}31.4 \\
5\end{array}$ & 1.57 & $\begin{array}{c}0.5 \\
0\end{array}$ & 0 & 0 & 0 & $\begin{array}{c}24 \\
1\end{array}$ & $\begin{array}{c}18 \\
0\end{array}$ & $\begin{array}{l}\text { If the patient is using the } \\
\text { clinical shortness next to his } \\
\text { bed, they are cleaned and } \\
\text { cleared at least daily and } \\
\text { when they are contaminated }\end{array}$ & 0 & 0 & 80 & $\begin{array}{c}12 \\
0\end{array}$ & $\begin{array}{c}22 \\
1\end{array}$ & $\begin{array}{c}4.3 \\
3\end{array}$ & $\begin{array}{c}0.7 \\
8\end{array}$ & $\begin{array}{c}86.7 \\
0\end{array}$ & 3 \\
\hline \multicolumn{19}{|c|}{ 5- Isolation room cleaning producers } \\
\hline 4 & $\begin{array}{c}64.8 \\
9\end{array}$ & 3.24 & $\begin{array}{c}0.7 \\
5\end{array}$ & 0 & $\begin{array}{c}18 \\
1\end{array}$ & $\begin{array}{c}16 \\
2\end{array}$ & 78 & 0 & $\begin{array}{l}\text { Wear personal protective } \\
\text { equipment during work }\end{array}$ & 0 & 0 & 0 & $\begin{array}{c}18 \\
2\end{array}$ & $\begin{array}{c}23 \\
9\end{array}$ & $\begin{array}{c}4.5 \\
7\end{array}$ & $\begin{array}{c}0.5 \\
0\end{array}$ & $\begin{array}{c}91.3 \\
5\end{array}$ & $8 *$ \\
\hline $7 *$ & $\begin{array}{c}58.1 \\
0\end{array}$ & 2.91 & $\begin{array}{c}0.6 \\
8\end{array}$ & 0 & 80 & $\begin{array}{c}22 \\
1\end{array}$ & $\begin{array}{c}12 \\
0\end{array}$ & 0 & $\begin{array}{l}\text { Application of health safety } \\
\text { measures }\end{array}$ & 0 & & 80 & $\begin{array}{c}16 \\
0\end{array}$ & $\begin{array}{c}18 \\
1\end{array}$ & $\begin{array}{c}4.2 \\
4\end{array}$ & $\begin{array}{c}0.7 \\
5\end{array}$ & $\begin{array}{c}84.8 \\
0\end{array}$ & 13 \\
\hline 1 & $\begin{array}{c}72.4 \\
0\end{array}$ & 3.62 & $\begin{array}{c}0.4 \\
9\end{array}$ & 0 & $\begin{array}{c}26 \\
1\end{array}$ & $\begin{array}{c}16 \\
0\end{array}$ & 0 & 0 & $\begin{array}{l}\text { Empty t garbage containers } \\
\text { and keep them washed and } \\
\text { disinfected. }\end{array}$ & 0 & 0 & 0 & 80 & $\begin{array}{c}34 \\
1\end{array}$ & $\begin{array}{c}4.8 \\
1\end{array}$ & $\begin{array}{c}0.3 \\
9\end{array}$ & $\begin{array}{c}96.2 \\
0\end{array}$ & 2 \\
\hline 2 & $\begin{array}{c}70.5 \\
9\end{array}$ & 3.53 & $\begin{array}{c}0.5 \\
0\end{array}$ & 0 & $\begin{array}{c}22 \\
3\end{array}$ & $\begin{array}{c}19 \\
8\end{array}$ & 0 & 0 & $\begin{array}{c}\text { Removal of infectious waste } \\
\text { if necessary }\end{array}$ & 0 & 0 & 0 & $\begin{array}{c}16 \\
0\end{array}$ & $\begin{array}{c}26 \\
1\end{array}$ & $\begin{array}{c}4.6 \\
2\end{array}$ & $\begin{array}{c}0.4 \\
9\end{array}$ & $\begin{array}{c}92.4 \\
0\end{array}$ & 6 \\
\hline 5 & $\begin{array}{c}40.5 \\
2\end{array}$ & 2.03 & $\begin{array}{c}0.7 \\
7\end{array}$ & 0 & 0 & $\begin{array}{c}13 \\
1\end{array}$ & $\begin{array}{c}17 \\
0\end{array}$ & $\begin{array}{c}12 \\
0\end{array}$ & $\begin{array}{l}\text { Collect linens and gown for } \\
\text { patients isolated in red bags } \\
\text { in red and put a card in red } \\
\text { ink }\end{array}$ & 0 & 118 & $\begin{array}{c}16 \\
9\end{array}$ & $\begin{array}{c}13 \\
4\end{array}$ & 0 & $\begin{array}{c}3.0 \\
4\end{array}$ & $\begin{array}{c}0.7 \\
7\end{array}$ & $\begin{array}{c}60.7 \\
6\end{array}$ & 5 \\
\hline & & & & & & & & & only one-time cleaning pieces & & & & & & & & & \\
\hline 17 & 31.4 & 1.57 & 0.5 & 0 & 0 & 0 & 24 & 18 & Clean the spot of the walls & 0 & 0 & 76 & 12 & 22 & 4.3 & 0.7 & 87.0 & 12 \\
\hline
\end{tabular}


International Journal of Heritage, Tourism and Hospitality Vol. (12), No. (2/2), September, 2018

By: Faculty of Tourism and Hotels, Fayoum University, Egypt

\begin{tabular}{|c|c|c|c|c|c|c|c|c|c|c|c|c|c|c|c|c|c|c|}
\hline & 5 & & 0 & & & & 1 & 0 & & & & & 0 & 5 & 5 & 7 & 8 & \\
\hline 6 & $\begin{array}{c}58.6 \\
2\end{array}$ & 2.93 & $\begin{array}{c}0.8 \\
3\end{array}$ & 0 & $\begin{array}{c}13 \\
1\end{array}$ & $\begin{array}{c}13 \\
0\end{array}$ & $\begin{array}{c}16 \\
0\end{array}$ & 0 & $\begin{array}{l}\text { Scan the door frame, } \\
\text { furniture bumpers and chairs }\end{array}$ & 0 & 0 & 58 & 80 & $\begin{array}{c}28 \\
3\end{array}$ & $\begin{array}{c}4.5 \\
3\end{array}$ & $\begin{array}{c}0.7 \\
2\end{array}$ & $\begin{array}{c}90.6 \\
9\end{array}$ & 9 \\
\hline 14 & $\begin{array}{c}42.7 \\
6\end{array}$ & 2.14 & $\begin{array}{c}0.7 \\
7\end{array}$ & 0 & 0 & $\begin{array}{c}15 \\
8\end{array}$ & $\begin{array}{c}16 \\
3\end{array}$ & $\begin{array}{c}10 \\
0\end{array}$ & $\begin{array}{l}\text { Wipe the window sill and any } \\
\text { spots with a gap }\end{array}$ & 0 & 0 & $\begin{array}{c}15 \\
2\end{array}$ & $\begin{array}{c}18 \\
1\end{array}$ & 88 & $\begin{array}{c}3.8 \\
5\end{array}$ & $\begin{array}{c}0.7 \\
4\end{array}$ & $\begin{array}{c}76.9 \\
6\end{array}$ & 15 \\
\hline 10 & $\begin{array}{c}53.3 \\
5\end{array}$ & 2.67 & $\begin{array}{c}0.4 \\
7\end{array}$ & 0 & & $\begin{array}{c}28 \\
1\end{array}$ & $\begin{array}{c}14 \\
0\end{array}$ & 0 & $\begin{array}{l}\text { Survey all vertical surfaces, } \\
\text { counters, edges and door sills }\end{array}$ & 0 & 0 & $\begin{array}{c}15 \\
2\end{array}$ & 80 & $\begin{array}{c}18 \\
9\end{array}$ & $\begin{array}{c}4.0 \\
9\end{array}$ & $\begin{array}{c}0.9 \\
0\end{array}$ & $\begin{array}{c}81.7 \\
6\end{array}$ & 14 \\
\hline 16 & $\begin{array}{c}40.0 \\
0\end{array}$ & 2.00 & $\begin{array}{c}0.6 \\
2\end{array}$ & 0 & 0 & 80 & $\begin{array}{c}26 \\
1\end{array}$ & 80 & $\begin{array}{c}\text { Clear all surfaces of the front } \\
\text { panel, fence, and remote } \\
\text { controls }\end{array}$ & 0 & 0 & $\begin{array}{c}11 \\
8\end{array}$ & $\begin{array}{c}30 \\
3\end{array}$ & 0 & $\begin{array}{c}3.7 \\
2\end{array}$ & $\begin{array}{c}0.4 \\
5\end{array}$ & $\begin{array}{c}74.3 \\
9\end{array}$ & 16 \\
\hline 5 & $\begin{array}{c}62.6 \\
1\end{array}$ & 3.13 & $\begin{array}{c}0.6 \\
9\end{array}$ & 0 & $\begin{array}{c}13 \\
1\end{array}$ & $\begin{array}{c}21 \\
4\end{array}$ & 76 & 0 & Change of bed linen & 0 & 0 & 0 & $\begin{array}{c}16 \\
2\end{array}$ & $\begin{array}{c}25 \\
9\end{array}$ & $\begin{array}{c}4.6 \\
2\end{array}$ & $\begin{array}{c}0.4 \\
9\end{array}$ & $\begin{array}{c}92.3 \\
0\end{array}$ & 7 \\
\hline 3 & $\begin{array}{c}67.6 \\
5\end{array}$ & 3.38 & $\begin{array}{c}0.4 \\
9\end{array}$ & 0 & $\begin{array}{c}16 \\
1\end{array}$ & $\begin{array}{c}26 \\
0\end{array}$ & 0 & 0 & $\begin{array}{c}\text { Disinfect phone arm and light } \\
\text { switches, knobs and other } \\
\text { high-touch areas }\end{array}$ & 0 & 0 & 0 & $\begin{array}{c}12 \\
0\end{array}$ & $\begin{array}{c}30 \\
1\end{array}$ & $\begin{array}{c}4.7 \\
2\end{array}$ & $\begin{array}{c}0.4 \\
5\end{array}$ & $\begin{array}{c}94.3 \\
0\end{array}$ & $5 *$ \\
\hline & & \multicolumn{15}{|c|}{$\begin{array}{l}\text { Wear single-use protective clothing (PPE) such as gloves, headgear, shoes, etc. contaminated with medicine. } \\
\text { When dealing with }\end{array}$} & & \\
\hline $7 *$ & $\begin{array}{c}58.1 \\
0\end{array}$ & 2.91 & $\begin{array}{c}0.6 \\
8\end{array}$ & 0 & 80 & $\begin{array}{c}22 \\
1\end{array}$ & $\begin{array}{c}12 \\
0\end{array}$ & 0 & $\begin{array}{l}\text { Contaminants from the } \\
\text { preparation of the medicine } \\
\text { and the tools used in giving it } \\
\text { to the patient such as } \\
\text { syringes, needles and } \\
\text { preparation utensils }\end{array}$ & 0 & 0 & 0 & $\begin{array}{c}10 \\
0\end{array}$ & $\begin{array}{c}32 \\
1\end{array}$ & $\begin{array}{c}4.7 \\
6\end{array}$ & $\begin{array}{c}0.4 \\
3\end{array}$ & $\begin{array}{c}95.2 \\
5\end{array}$ & 3 \\
\hline 3 & $\begin{array}{c}52.4 \\
0\end{array}$ & 2.62 & $\begin{array}{c}0.4 \\
9\end{array}$ & 0 & 0 & $\begin{array}{c}26 \\
1\end{array}$ & $\begin{array}{c}16 \\
0\end{array}$ & 0 & $\begin{array}{l}\text { Expired medicines, excess } \\
\text { quantities when preparing the } \\
\text { medicine, and excess } \\
\text { medicines and return from } \\
\text { the treatment departments }\end{array}$ & 0 & 0 & 0 & $\begin{array}{c}18 \\
2\end{array}$ & $\begin{array}{c}23 \\
9\end{array}$ & $\begin{array}{c}4.5 \\
7\end{array}$ & $\begin{array}{c}0.5 \\
0\end{array}$ & $\begin{array}{c}91.3 \\
5\end{array}$ & 8* \\
\hline $\begin{array}{c}12 \\
*\end{array}$ & $\begin{array}{c}48.6 \\
0\end{array}$ & 2.43 & $\begin{array}{c}0.5 \\
0\end{array}$ & 0 & 0 & $\begin{array}{c}18 \\
1\end{array}$ & $\begin{array}{c}24 \\
0\end{array}$ & 0 & $\begin{array}{l}\text { Urine and stool and vomiting } \\
\text { patient, which contains } \\
\text { dangerous amounts of these } \\
\text { drugs for } 48 \text { hours and } \\
\text { sometimes may be up to a }\end{array}$ & 0 & 0 & 0 & $\begin{array}{c}12 \\
0\end{array}$ & $\begin{array}{c}30 \\
1\end{array}$ & $\begin{array}{c}4.7 \\
2\end{array}$ & $\begin{array}{c}0.4 \\
5\end{array}$ & $\begin{array}{c}94.3 \\
0\end{array}$ & $5 *$ \\
\hline
\end{tabular}


International Journal of Heritage, Tourism and Hospitality Vol. (12), No. (2/2), September, 2018

By: Faculty of Tourism and Hotels, Fayoum University, Egypt

\begin{tabular}{|c|c|c|c|c|c|c|c|c|c|c|c|c|c|c|c|c|c|c|}
\hline & & & & & & & & & $\begin{array}{l}\text { week of giving the patient } \\
\text { medicine. }\end{array}$ & & & & & & & & & \\
\hline 15 & $\begin{array}{c}42.6 \\
6\end{array}$ & 2.13 & $\begin{array}{c}0.7 \\
0\end{array}$ & 0 & & $\begin{array}{c}13 \\
4\end{array}$ & $\begin{array}{c}20 \\
9\end{array}$ & 78 & $\begin{array}{c}\text { Remnants of medicine cans } \\
\text { and bottles }\end{array}$ & 0 & 0 & 76 & $\begin{array}{c}11 \\
8\end{array}$ & $\begin{array}{c}22 \\
7\end{array}$ & $\begin{array}{c}4.3 \\
6\end{array}$ & $\begin{array}{c}0.7 \\
7\end{array}$ & $\begin{array}{c}87.1 \\
7\end{array}$ & 11 \\
\hline 9 & $\begin{array}{c}57.2 \\
4\end{array}$ & 2.86 & $\begin{array}{c}0.6 \\
4\end{array}$ & 0 & 62 & $\begin{array}{c}23 \\
9\end{array}$ & $\begin{array}{c}12 \\
0\end{array}$ & 0 & $\begin{array}{l}\text { Some air fresheners used in } \\
\text { the medicine preparation } \\
\text { compartment. }\end{array}$ & 0 & 0 & 0 & 76 & $\begin{array}{c}34 \\
5\end{array}$ & $\begin{array}{c}4.8 \\
2\end{array}$ & $\begin{array}{c}0.3 \\
9\end{array}$ & $\begin{array}{c}96.3 \\
9\end{array}$ & 1 \\
\hline 11 & $\begin{array}{c}48.7 \\
9\end{array}$ & 2.44 & $\begin{array}{c}0.7 \\
9\end{array}$ & 0 & 0 & $\begin{array}{c}26 \\
5\end{array}$ & 76 & 80 & $\begin{array}{l}\text { Remnants of plastic bags and } \\
\text { tubes used for intravenous } \\
\text { feeding through which the } \\
\text { drug is injected into the } \\
\text { patient's body. }\end{array}$ & 0 & 0 & 0 & $\begin{array}{c}11 \\
4\end{array}$ & $\begin{array}{c}30 \\
7\end{array}$ & $\begin{array}{c}4.7 \\
3\end{array}$ & $\begin{array}{c}0.4 \\
4\end{array}$ & $\begin{array}{c}94.5 \\
8\end{array}$ & 4 \\
\hline 13 & $\begin{array}{c}47.5 \\
5\end{array}$ & 2.38 & $\begin{array}{c}0.7 \\
9\end{array}$ & 0 & 0 & $\begin{array}{c}23 \\
9\end{array}$ & $\begin{array}{c}10 \\
2\end{array}$ & 80 & $\begin{array}{c}\text { Cotton cloths used to clean } \\
\text { up spilled chemical } \\
\text { medicines. }\end{array}$ & 0 & 0 & 56 & 76 & $\begin{array}{c}28 \\
9\end{array}$ & $\begin{array}{c}4.5 \\
5\end{array}$ & $\begin{array}{c}0.7 \\
2\end{array}$ & $\begin{array}{c}91.0 \\
7\end{array}$ & 6 \\
\hline $\begin{array}{c}12 \\
*\end{array}$ & $\begin{array}{c}48.5 \\
0\end{array}$ & 2.43 & $\begin{array}{c}0.7 \\
4\end{array}$ & 0 & 0 & $\begin{array}{c}24 \\
1\end{array}$ & $\begin{array}{c}11 \\
8\end{array}$ & 62 & $\begin{array}{c}\text { gauze and patient's } \\
\text { contaminated ligament }\end{array}$ & 0 & 0 & 66 & 66 & $\begin{array}{c}28 \\
9\end{array}$ & $\begin{array}{c}4.5 \\
3\end{array}$ & $\begin{array}{c}0.7 \\
5\end{array}$ & $\begin{array}{c}90.5 \\
9\end{array}$ & 10 \\
\hline
\end{tabular}


On the other hand for the governmental hospitals results showed that Both employees wear a special clean uniform, and employees avoid using pillowcase, sheets or towels for cleaning, comes in the first rank with a percentage estimated at (72.40) of answers; followed by employees avoid Spitting on the floor in work and back areas recorded the second rank with percentage of (60.52) of responses; While, Employees avoid chewing gum at work comes on the third rank by average (46.70) of answers; Moreover, employees knows sanitation and hygiene rules the fourth rank with the ratio of (44.70) of responses; Furthermore, employees changes uniform daily come as the fifth rank by average (34.30) of answers. These results disagree with opining of (kayakalp 2015).

Regarding respondents' opinion regarding patient room cleaning producers employees do, the respondents' perceptions came and ranked as follows; the private hospitals remove the gloves, and make the hands clean after work were considered the highest level factor with weighted average (96.20), followed by Review the room, change the furnishings and collect the remains of the medicine preparation boxes and the tools used to give the patient such as injections, needles and preparation utensils in the second position by weighted average (94.30) This result agree with opining of (Elizabeth, 2014)..Moreover, Cleaning and disinfection of the surface of the type frequent touch: such as edges and bedspreads - door handles - table adjacent to the patient - telephone - nurse call buttons - TV remote - lighting switches must be cleaned and purified realized the third position by weighted average (93.35). Garbage containers with holes or openings that allow fluid and waste to enter in the fourth position by weighted average (92.40). While, garbage containers covered with tight cover achieved the fifth position by weighted average (90.50).

On the other hand for the governmental hospitals results showed that review the room, change the furnishings and collect the remains of the medicine preparation boxes and the tools used to give the patient such as injections, needles and preparation utensils were considered the highest level factor with weighted average (66.70), followed by Remove the gloves, and make the hands clean after work by weighted average (50.50). Moreover, cleaning and cleaning horizontal surfaces: including tables, beds, chairs, edges, lighting and wall fixtures realized the third position by weighted average (44.80). Cleaning and disinfection of the surface of the type frequent touch: such as edges and bedspreads - door handles - table adjacent to the patient - telephone - nurse call buttons - TV remote - lighting switches must be cleaned and purified in the fourth position by weighted average (42.90). While, Both cleaning walls, windows and doors: including door handles, and garbage containers with tight cover were achieved the fifth position by weighted average (38.62).

Concerning respondents' opinion regarding patient room cleaning bathroom producers' employees do, the respondents' perceptions can be ranked as follows; the private hospitals Disinfect toilet, comes in the first rank with a percentage estimated at (93.35) of answers; followed by restock consumable supplies recorded the second rank with percentage of (92.30) of responses; While, If the patient is using the clinical shortness next to his bed, they are cleaned and cleared at least daily and when they are contaminated comes on the third rank by average (86.70) of answers; Moreover, Clean the mirror using a blue Microfiber glass cloth the fourth rank with the ratio of (66.70) of responses; Furthermore, Clean the sink area, including the counter, faucet and handles, and sink basin with a clean yellow Microfiber cloth come as the fifth rank by average (60.52) of answers. 
On the other hand for the governmental hospitals results showed that restock consumable supplies, comes in the first rank with a percentage estimated at (46.70) of answers; followed by disinfect toilet recorded the second rank with percentage of (43.85) of responses; While, clean the sink area, including the counter, faucet and handles, and sink basin with a clean yellow Microfiber cloth disinfect toilet comes on the third rank by average ( 31.54) of answers; Moreover, the patient is using the clinical shortness next to his bed, they are cleaned and cleared at least daily and when they are contaminated the fourth rank with the ratio of (31.45) of responses; Furthermore, Clean the mirror using a blue Microfiber glass cloth come as the fifth rank by average (26.37) of answers. These results disagree with (Otter, Yezli \& French, 2015).

Concerning respondents' opinion regarding Isolation room cleaning producers, the respondents' perceptions came and ranked as follows; the private hospitals wear single-use protective clothing (PPE) such as gloves, headgear, shoes, etc. contaminated with medicine when dealing with some air fresheners used in the medicine preparation compartment were considered the highest level factor with weighted average (96.39), followed by Empty $t$ garbage containers and keep them washed and disinfected in the second position by weighted average (96.20).Moreover, Wear single-use protective clothing (PPE) when dealing with Contaminants from the preparation of the medicine and the tools used in giving it to the patient such as syringes, needles and preparation utensils realized the third position by weighted average (95.25). Remnants of plastic bags and tubes used for intravenous feeding through which the drug is injected into the patient's body were in the fourth position by weighted average (94.58). While, Both disinfect phone arm and light switches, knobs and other high-touch areas and Urine and stool and vomiting patient, which contains dangerous amounts of these drugs for 48 hours and sometimes may be up to a week of giving the patient medicine achieved the fifth position by weighted average (94.30).

On the other hand for the governmental hospitals results showed that empty the garbage containers and keep them washed and disinfected were considered the highest level factor with weighted average (72.40), followed by removal of infectious waste if necessary by weighted average (70.59). Moreover, disinfect phone arm and light switches, knobs and other high-touch areas realized the third position by weighted average (67.65). Wear personal protective equipment during work were in the fourth position by weighted average (64.89). While, Use only one-time cleaning pieces for change of bed linen were achieved the fifth position by weighted average (62.61) this result agree with opining of (Rutala, 2013).

Towards ranking the main group factors averages of the level of housekeeping in the governmental and private hospitals from the patients and their families' point of view as shown in table (4), the results showed that:

The private hospitals have the top ranking levels from the respondents' points of view as follows:

1.Wear single-use protective clothing was the $1^{\text {st }}$ Excellency weighted average with a mean (4.62) and std. deviation (.51).

2.Patient room cleaning producers that employees do were the $2^{\text {nd }}$ Excellency weighted average with a mean (4.35) and std. deviation (.44).

3.Regarding $3^{\text {rd }}$ level weighted average were use only one-time cleaning pieces with a mean (4.26) and std. deviation (.59). 
4.In the $4^{\text {th }}$ position was Isolation room cleaning producers, with a mean $(4.25)$ and std. deviation (.55).

5.Concerning the $5^{\text {th }}$ level weighted average was regarding agree with that Patient room cleaning bathroom producers employees do, with mean (3.99) and std. deviation (.61).

6.In accordance to the $6^{\text {th }}$ weighted average level were personal hygiene habits with mean (3.87) and std. deviation (.60).

7.Basic procedures coming in the $7^{\text {th }}$ level to the respondents with mean was (3.63) and std. deviation (.58).

Table 5: Descriptive statistics for the main group factors averages

\begin{tabular}{|c|c|c|c|c|c|c|c|c|c|c|}
\hline \multicolumn{5}{|c|}{$\begin{array}{l}\text { Governmental hospitals } \\
\text { evaluation }\end{array}$} & & \multicolumn{5}{|c|}{ Private hospitals evaluations } \\
\hline \multirow{2}{*}{$\stackrel{\infty}{. \Xi}$} & \multicolumn{2}{|c|}{ Mean } & \multirow{2}{*}{ 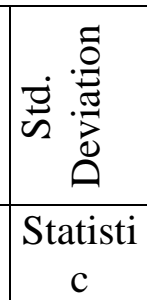 } & \multirow{2}{*}{ Code } & \multirow[b]{2}{*}{ Average } & \multirow[b]{2}{*}{ Code } & \multicolumn{2}{|c|}{ Mean } & \multirow{2}{*}{ 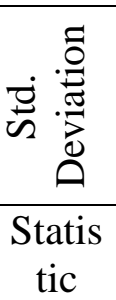 } & \multirow{2}{*}{ 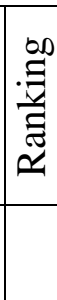 } \\
\hline & $\begin{array}{l}\text { Stati } \\
\text { stic }\end{array}$ & $\begin{array}{l}\text { Std. } \\
\text { Error }\end{array}$ & & & & & $\begin{array}{l}\text { Statisti } \\
\text { c }\end{array}$ & $\begin{array}{l}\text { Std. } \\
\text { Error }\end{array}$ & & \\
\hline 6 & $\begin{array}{r}2.11 \\
23\end{array}$ & .03277 & .67247 & ahany & $\begin{array}{l}\text { 1- Basic } \\
\text { procedures }\end{array}$ & hanya & 3.6340 & .02859 & $\begin{array}{r}.5866 \\
9\end{array}$ & 7 \\
\hline 4 & $\begin{array}{r}2.33 \\
60\end{array}$ & .02694 & .55284 & bhany & 2- Personal hygiene habits & hanyb & 3.8731 & .02938 & $\begin{array}{r}.6027 \\
4\end{array}$ & 6 \\
\hline 5 & $\begin{array}{r}2.27 \\
52 \\
\end{array}$ & .03344 & .68621 & chany & $\begin{array}{l}\text { 3. Patient room cleaning } \\
\text { producers employees do. }\end{array}$ & hanyc & 4.3546 & .02189 & $\begin{array}{r}.4491 \\
2 \\
\end{array}$ & 2 \\
\hline 7 & $\begin{array}{r}1.79 \\
90\end{array}$ & .02760 & .56636 & dhany & $\begin{array}{l}\text { 4- Patient room cleaning } \\
\text { bathroom producers } \\
\text { employees do }\end{array}$ & hanyd & 3.9957 & .03008 & $\begin{array}{r}.6172 \\
8\end{array}$ & 5 \\
\hline 1 & $\begin{array}{r}3.06 \\
51\end{array}$ & .02855 & .58574 & ehany & $\begin{array}{l}\text { 5- Isolation room cleaning } \\
\text { producers }\end{array}$ & hanye & 4.2551 & .02559 & $\begin{array}{r}.5250 \\
0 \\
\end{array}$ & 4 \\
\hline 2 & $\begin{array}{r}2.54 \\
60 \\
\end{array}$ & .02745 & .56328 & fhany & $\begin{array}{l}6 \text { - Use only one-time } \\
\text { cleaning pieces }\end{array}$ & hanyf & 4.2677 & .02898 & $\begin{array}{r}.5946 \\
9 \\
\end{array}$ & 3 \\
\hline 3 & $\begin{array}{r}2.52 \\
40\end{array}$ & .02943 & 60379 & $\begin{array}{l}\text { Ghan } \\
\mathrm{y}\end{array}$ & $\begin{array}{l}\text { 7- Wear single-use } \\
\text { protective clothing. }\end{array}$ & hanyg & 4.6295 & .02508 & $\begin{array}{r}.5146 \\
8\end{array}$ & 1 \\
\hline
\end{tabular}

On the other hand, the $2^{\text {nd }}$ ranking level by the governmental hospitals in accordance to the respondents' points of view as follows:

1. Isolation room cleaning producers was the 1st Excellency weighted average with a mean (3.06) and std. deviation (.58).

2. Patient room cleaning producers that employees do were the $2^{\text {nd }}$ Excellency weighted average with a mean (2.54) and std. deviation (.56).

3 . Regarding $3^{\text {rd }}$ level weighted average were wear single-use protective clothing with a mean (2.52) and std. deviation (.60).

4. In the $4^{\text {th }}$ position were personal hygiene habits, with a mean (2.33) and std. deviation (.55).

5. Concerning the $5^{\text {th }}$ level weighted average was regarding agree with that Patient room cleaning producers employees do, with mean (2.27) and std. deviation (.68).

6. In accordance to the $6^{\text {th }}$ weighted average level were basic procedures with mean (2.11) and std. deviation (.67). 
Patient room cleaning bathroom producers those employees do coming in the $7^{\text {th }}$ level to the respondents with mean was (1.79) and std. deviation (.56).

Prior to research reliability and testing the hypotheses, it is important to establish the reliability of each of the items used in this study. Reliability judges are the degree to which measures are free from error, yielding consistent results. Descriptive Statistics Means, and Standard deviation, Std. Error Mean was shown in tables (4 and 5). Moreover, Regarding H1 Research correlations were tested using Pearson product-moment correlation co efficient. Preliminary analyses were performed to ensure no violation of assumptions' of normality and linearity. Table (6) shows that there are strong correlations between all the proposed relations in the conceptual model with (r) values ranging from (.854 to .988), $(\mathrm{P}<$ $.005)$ and the obtained correlation value are in the expected positive direction. Based on the results of Pearson correlation analysis which represent proposed liner relationships, the research hypotheses were fully supported.

Table 6: Summary of correlation analysis accordance to Pearson correlation ( N. 421).

\begin{tabular}{|c|c|c|c|c|c|c|c|c|c|c|c|c|c|c|}
\hline & $\begin{array}{c}\text { ahan } \\
\mathrm{y} \\
\end{array}$ & \begin{tabular}{|c|} 
bhan \\
$y$
\end{tabular} & $\begin{array}{c}\text { chan } \\
\mathrm{y}\end{array}$ & \begin{tabular}{|c|} 
dhan \\
$y$
\end{tabular} & $\begin{array}{c}\text { ehan } \\
y\end{array}$ & fhany & $\begin{array}{c}\text { Ghan } \\
\mathrm{y}\end{array}$ & $\begin{array}{c}\text { hany } \\
\text { a }\end{array}$ & $\begin{array}{c}\text { hany } \\
\text { b }\end{array}$ & $\begin{array}{c}\text { hany } \\
\mathrm{c}\end{array}$ & $\begin{array}{c}\text { hany } \\
\text { d }\end{array}$ & $\begin{array}{c}\text { hany } \\
\mathrm{e}\end{array}$ & hanyf & f $\begin{array}{c}\text { hany } \\
\mathrm{g}\end{array}$ \\
\hline ahany & 1 & & & & & & & & & & & & & \\
\hline bhany & $.986^{*}$ & 1 & & & & & & & & & & & & \\
\hline chany & $.988^{*}$ & $985^{*}$ & 1 & & & & & & & & & & & \\
\hline dhany & $.967^{*}$ & $\begin{array}{c}979^{*} \\
*\end{array}$ & $\begin{array}{c}972^{*} \\
*\end{array}$ & 1 & & & & & & & & & & \\
\hline ehany & $.991^{*}$ & $\begin{array}{c}989^{*} \\
*\end{array}$ & ${ }_{*}^{986^{*}}$ & $975^{*}$ & 1 & & & & & & & & & \\
\hline fhany & $.987^{*}$ & $\begin{array}{c}976^{*} \\
*\end{array}$ & ${ }_{*}^{981^{*}}$ & $958^{*}$ & $982^{* *}$ & 1 & & & & & & & & \\
\hline $\begin{array}{c}\text { Ghan } \\
y\end{array}$ & $.974^{*}$ & $979^{*}$ & ${ }_{*}^{961^{*}}$ & $966^{*}$ & $984^{* *}$ & $971^{* *}$ & 1 & & & & & & & \\
\hline hanya & $.989^{*}$ & $\begin{array}{c}990^{*} \\
*\end{array}$ & $\begin{array}{c}979^{*} \\
*\end{array}$ & $.964^{*}$ & $988^{* *}$ & $978^{* *}$ & $978^{* * *}$ & 1 & & & & & & \\
\hline hanyb & $.975^{*}$ & $970^{*}$ & $\begin{array}{c}958^{*} \\
*\end{array}$ & $.963^{*}$ & $978^{* * *}$ & $959^{* *}$ & $988^{* *}$ & $974^{* * *}$ & 1 & & & & & \\
\hline hanyc & $.906^{*}$ & $939^{*}$ & $914^{*}$ & $940^{*}$ & $938^{* *}$ & $903^{* *}$ & $961^{* *}$ & $922^{* *}$ & $948^{* * *}$ & 1 & & & & \\
\hline hanyd & $.962^{*}$ & $972^{*}$ & $\begin{array}{c}956^{*} \\
*\end{array}$ & .978* & $978^{* *}$ & $956^{* *}$ & $984^{* * *}$ & $963^{* *}$ & $982^{* *}$ & $976^{* *}$ & 1 & & & \\
\hline hanye & $.972^{*}$ & $974^{*}$ & $970^{*}$ & $976^{*}$ & $983^{* *}$ & $973^{* * *}$ & $991^{* * *}$ & $967^{* *}$ & $984^{* *}$ & $958^{* *}$ & $988^{* * *}$ & 1 & & \\
\hline hanyf & $.947^{*}$ & $\begin{array}{c}963^{*} \\
*\end{array}$ & $\begin{array}{c}945^{*} \\
*\end{array}$ & .959* & $971^{* *}$ & $941^{* * *}$ & $982^{* * *}$ & $957^{* *}$ & $970^{* *}$ & $985^{* *}$ & $986^{* *}$ & $\mid 977^{* *}$ & 1 & \\
\hline hanyg & $.878^{*}$ & $883^{*}$ & $854^{*}$ & $894^{*}$ & $907^{* *}$ & $875^{* *}$ & $949^{* * *}$ & $885^{* * *}$ & $946^{* *}$ & $956^{* *}$ & $951^{* * *}$ & $* 941^{* *}$ & $\mid 958^{* * *}$ & 1 \\
\hline
\end{tabular}


International Journal of Heritage, Tourism and Hospitality Vol. (12), No. (2/2), September, 2018 By: Faculty of Tourism and Hotels, Fayoum University, Egypt

Table 7: Independent Samples Test $(\mathrm{N}=421)$

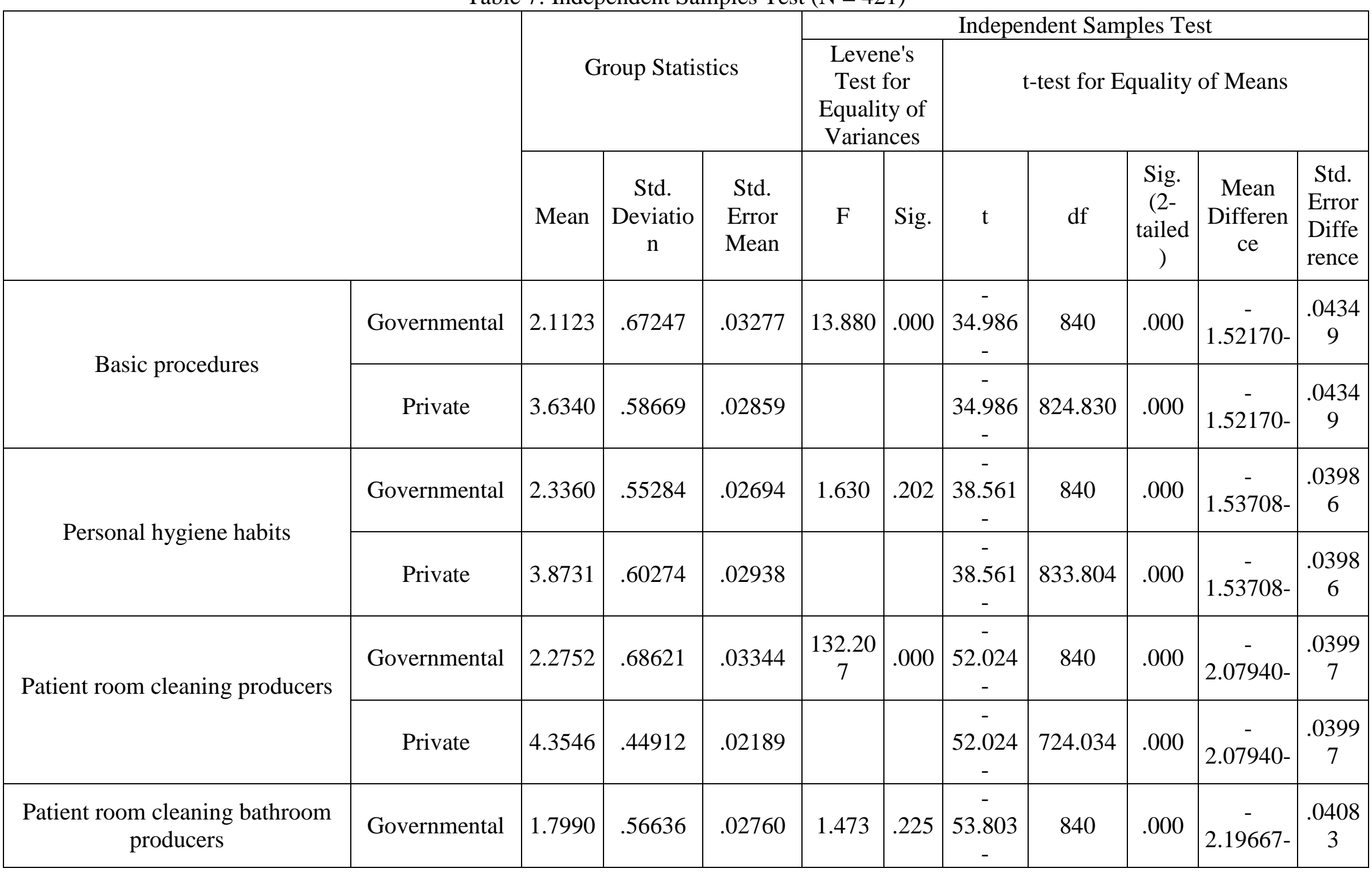


International Journal of Heritage, Tourism and Hospitality Vol. (12), No. (2/2), September, 2018 By: Faculty of Tourism and Hotels, Fayoum University, Egypt

\begin{tabular}{|c|c|c|c|c|c|c|c|c|c|c|c|}
\hline & Private & 3.9957 & .61728 & .03008 & & & $\begin{array}{c}- \\
53.803 \\
-\end{array}$ & 833.850 & .000 & $\begin{array}{c}- \\
2.19667-\end{array}$ & $\begin{array}{c}.0408 \\
3\end{array}$ \\
\hline \multirow{2}{*}{ Isolation room cleaning producers } & Governmental & 3.0651 & .58574 & .02855 & 8.184 & .004 & $\begin{array}{c}- \\
31.042 \\
-\end{array}$ & 840 & .000 & $\begin{array}{c}- \\
1.19002-\end{array}$ & $\begin{array}{c}.0383 \\
4\end{array}$ \\
\hline & Private & 4.2551 & .52500 & .02559 & & & $\begin{array}{c}- \\
31.042 \\
-\end{array}$ & 830.130 & .000 & $\begin{array}{c}- \\
1.19002-\end{array}$ & $\begin{array}{c}.0383 \\
4\end{array}$ \\
\hline \multirow{2}{*}{ Use only one-time cleaning pieces } & Governmental & 2.5460 & .56328 & .02745 & 10.654 & .001 & $\begin{array}{c}- \\
43.129 \\
-\end{array}$ & 840 & .000 & $\begin{array}{c}- \\
1.72175-\end{array}$ & $\begin{array}{c}.0399 \\
2\end{array}$ \\
\hline & Private & 4.2677 & .59469 & .02898 & & & $\begin{array}{c}- \\
43.129 \\
-\end{array}$ & 837.538 & .000 & $\begin{array}{c}- \\
1.72175-\end{array}$ & $\begin{array}{c}.0399 \\
2\end{array}$ \\
\hline \multirow{2}{*}{$\begin{array}{l}\text { Wear single-use protective clothing } \\
\text { (PPE) such as gloves, headgear, } \\
\text { shoes, etc. contaminated with } \\
\text { medicine. }\end{array}$} & Governmental & 2.5382 & .59268 & .02889 & 28.240 & .000 & $\begin{array}{c}- \\
56.444 \\
-\end{array}$ & 840 & .000 & $\begin{array}{c}- \\
2.10553-\end{array}$ & $\begin{array}{c}.0373 \\
0\end{array}$ \\
\hline & Private & 4.6437 & .48431 & .02360 & & & $\begin{array}{c}- \\
56.444 \\
-\end{array}$ & 807.932 & .000 & $\begin{array}{c}- \\
2.10553-\end{array}$ & $\begin{array}{c}.0373 \\
0\end{array}$ \\
\hline
\end{tabular}


Moreover, regarding H2 "There is a significant difference between the housekeeping level in the governmental and private hospitals regarding the housekeeping quality in Egyptian hospitals" the results shown that there is a gap between the housekeeping quality level in the governmental and private hospitals and need to improve the quality level. Independent Samples Test $(\mathrm{N}=421)$ were used $(\mathrm{T}-$ test $)$ as shown in table (7).

\section{General Conclusion}

Housekeeping services in a hospital is entrusted with maintaining a hygienic and clean hospital environment conducive to patient care. There are some of the problems faced by any hospital. The literature supports our research on the relevance and importance of housekeeping procedures and safety in patient healthcare and hospitality, in an effort to improve patient care and their health. About population of the study this study geographical limit was the Egyptian hospitals in Cairo and Luxor and Aswan, through the period of May to August 2018. The questionnaire was divided into seven main sections: the first section: includes some of basic procedures. The second section: personal hygiene habits. The third section: focus on the patient room cleaning producers. The fourth section: patient room cleaning bathroom producers. The fifth section: isolation room cleaning producers. The sixth section: use only one-time cleaning pieces. The seventh section: wear single-use protective clothing (PPE) such as gloves, headgear, shoes, etc. contaminated with medicine. The chosen of hospitals was due to variety of the locations in Luxor and Aswan (16 hospitals).

The results showed that there are strong correlations between all the proposed relations (the basic procedures; personal hygiene habits; room cleaning producers; isolation room cleaning producers) in the conceptual model with (r) values ranging from (.854 to .988), $(\mathrm{P}<.005)$ and the obtained correlation value are in the expected positive direction. There is a gap between the housekeeping quality level in the governmental and private hospitals and need to improve the quality level.

Basic procedures need more care about many points such as waste bags shall be distributed according to the code coding policy. Provide separate buckets to clean the bathrooms and all the isolation rooms. Employees always knock and enter slowly, while cleaning the room. Train staff to know what cleaner to use for what surface. Employees' Smoking in work areas, Eating in work areas and touching their body parts not allowed. On the subject of personal hygiene habits more care should be taken on employees changes uniform daily; Employees knowledge about sanitation and hygiene rules.

Moreover, as regards patient room cleaning producers employees need to care about cleaning and cleaning horizontal surfaces: including tables, beds, chairs, edges, lighting and wall fixtures; Cleaning walls, windows and doors: including door handles; Garbage containers with tight cover. Concerning patient room cleaning bathroom producers employees should give more care about cleaning and cleaning horizontal surfaces: including tables, beds, chairs, edges, lighting and wall fixtures; Cleaning walls, windows and doors: including door handles; Garbage containers with tight cover.

Regarding, patient room cleaning bathroom producers employees could give more care about clean the mirror using a blue microfiber glass cloth; If the patient is using the clinical shortness next to his bed, they are cleaned and cleared at least daily and when they are contaminated; Clean the sink area, including the counter, faucet and handles, and sink basin with a clean yellow Microfiber cloth. Furthermore, should use 
only one-time cleaning pieces to clean the spot of the walls; Clear all surfaces of the front panel, fence, and remote controls; Wipe the window sill and any spots with a gap. Wear single-use protective clothing (PPE) such as gloves, headgear, shoes, etc. contaminated with medicine. When dealing with remnants of medicine cans and bottles; Cotton cloths used to clean up spilled chemical medicines; gauze and patient's contaminated ligament; Urine and stool and vomiting patient, which contains dangerous amounts of these drugs for 48 hours and sometimes may be up to a week of giving the patient medicine.

\section{Recommendations}

The hospital management should be organizing courses for housekeeping staff to train on:

1. Cleaning routines in the different areas of the hospital, including public areas, waiting rooms, general patient rooms, isolation rooms, bathrooms, and sluice rooms

2. The use of routine cleaning and terminal cleaning checklists

3. Cleaning methods and the appropriate use of cleaning equipment, detergents, and disinfectants

4. Waste and linen removal processes

5. Spills management

6. The importance of hand hygiene and correct hand hygiene methods

7. Correct use of PPE

8. Waste segregation and the safe handling of waste

9. Prevention of blood and body fluid exposure, including sharp safety and prompt reporting of incidents of exposure

10. Transmission risks in isolation rooms

\section{References}

Anderson RE, Young V, Stewart M, Robertson C, \& Dancer SJ. (2013) Cleanliness audit of clinical surfaces and equipment: who cleans what? J Hosp Infect pp.; $78: 178 \mathrm{e} 81$.

Branson, J., (2016) Hotel, Hostel and Hospital Housekeeping, fifth edition, printed in great britionloy page Bros, Norwich pp, 54, 60-68.

Carling PC, Bartley JM (2010) . Evaluating hygienic cleaning in health care settings: what you do not know can harm your patients. Am J Infect Control; 38(5):S41-50

Centers for Disease Control and Prevention, (2014) Options for evaluating environmental cleaning.. https:/www.cdc. gov/hai/toolkits/evaluatingenvironmental-cleaning.html. [Accessed 20 May 2017].

Gauthier J. (2004) Hospital clean" versus "construction clean - is there a difference? Can J Infect Control? 19-150-2.

Elizabeth, P., (2014) the Use of Facemasks and Respirators during an Influenza Pandemic: Scientific Evidence Base Review.

Hard R.( 1992) Hospitals look to Hospitality service firms to meet TQM goals. Hospitals; pp. 5: 56 - 58. 3

Hoes, C. (2013) Compliance safety vs. safety system, Journal of system, Vol.9 No.1, pp.4-5.

Johnson, D. (2004) Human resource management in the tourism industry", is publishing House of electronics industry, Beijing. 
Kayakalp,A (2015) National Guidelines for Clean Hospitals , Applicable to Tertiary Care Hospitals, Hospitals associated with Medical Colleges \& Super-specialty Hospitals in India, Ministry of health and family welfare government of Indin

Madhav., M(2016) Hospital Housekeeping: Emerging Issues and Future Dimensions.

Moore G, Muzslay M, Wilson APR (2013)The type, level, and distribution of microorganisms within the ward environment: a zonal analysis of an intensive care unit and a gastrointestinal surgical ward. Infect Control Hosp Epidemiol ; 34(5):500-6. 4.

Munoz-Price LS, Namias N, Cleary T, et al. (2013) Acinetobacter baumannii: association between environmental contamination of patient rooms and occupant status. Infect Control Hosp Epidemiol; 34(5):517-20.

Nosocomial infection (2009) Available at: http://en.wikipedia. Org / wiki nosocomial_infection. Accessed June 2009.

Navreet., A., (2016) Assistant Professor, Department of Community Medicine Govt. Medical College \& Hospital, Chandigarh. Biomedical Waste Management.

Otter JA, Yezli S \&French GL. (2015). The role played by contaminated surfaces in the transmission of nosocomial pathogens. Infect Control Hosp Epidemiol pp.; 32:68, 99.

Paraschivescu O., Cotarlat A., \& Putu T., (2011) Achieving Excellence through Professioalism, Management and Hospitality in Hospital"EconomyTransdisciplinarity Congnition Vol.15, issue 2/2011, pp.123131.

Pia Markkanen, ScD, Margaret Quinn ScD, CIH, Catherine Galligan, MSc\& Anila Bello, ScD (2009) Cleaning in Healthcare Facilities.

Prevention of hospital-acquired infections,(2002) A practical guide 2nd edition. World Health Organization Department of Communicable Disease, Surveillance and Response. Available at: http://www.who.int/csr/resources/publications/whoc dscsreph200212.pdf.

Rennie, M McGregor-Schuerman, I M Dale, C Robinson, R \& McWilliam (2006) Mercury poisoning after spillage at home from a sphygmomanometer on loan from hospital. British Medical Journal.

Russell AD, Hugo WB \& Ayliffe GAJ (1992) Principles and practice of disinfection, preservation and sterilization, 2nd ed. Oxford, Blackwell.

Rutala WA\& Weber DJ (2013) new disinfection and Sterilization methods. Emerg Infect Dis 7, 348-53

Satter B. \& Hall K. (2007) Healthy Choices; Transforming our Hospitals into Environmentally Healthy and Safe Places" A Scholarly Journal of the American Nurses Association. Vol. 12, No.2.

Vintila M. (2009) Health awareness and behavior of the elderly: between needs and reality". A comparative study @ Editura Universității de Vest Timişoara, Vol.11, Nr.2, 81-87.

WHO Guidelines on Hand Hygiene in Health Care (Advanced draft), at: http://www.who.int/patientsafety/information_centre/ghhad_ download/en/index.html. (Accessed 25/7/2018). 